\title{
In vivo Biosynthesis of Two Subunit Forms of Dopamine $\beta$-Hydroxylase in Rat Brain
}

\author{
Esther L. Sabban, ${ }^{1}$ Lorraine J. Kuhn, ${ }^{1}$ and Barry E. Levin ${ }^{2}$ \\ 'Department of Biochemistry, New York Medical College, Valhalla, New York 10595, and ${ }^{2}$ Neurology Service, Veterans \\ Administration Medical Center, East Orange, New Jersey 07019, and Department of Neurosciences, New Jersey Medical \\ School, Newark, New Jersey 07103
}

\begin{abstract}
In vivo biosynthesis of the 2 subunit forms of dopamine $\beta$-hydroxylase (DBH) was examined in the rat brain. ${ }^{35}$ S-methionine was injected into the noradrenergic neurons of the locus coeruleus (LC) using a stereotactic device. Several hours later, newly synthesized ${ }^{35}$ S-Met-labeled DBH was immunoprecipitated and quantitated. Both $M_{r}=77,000$ (77K) and 73,000 (73K) subunit forms were present in near-equal proportions after $4 \mathrm{hr}$ of labeling, and these were indistinguishable from those isolated from rat PC12 pheochromocytoma cells by electrophoretic mobility. Both forms sedimented with the vesicular subcellular fraction of LC homogenates, and a portion of the $73 \mathrm{~K}$ form could be released by hypotonic lysis of these vesicles. The 77K form predominated in the first $\mathbf{3 0}$ min labeling period, while the 73K form appeared more slowly over the next several hours. By $16 \mathrm{hr}$, the $73 \mathrm{~K}$ form comprised about $2 / 3$ of the total ${ }^{35} \mathrm{~S}$ Met-labeled DBH present. Inhibition of protein synthesis with puromycin 30 min after ${ }^{35}$ S-Met injection into the LC did not prevent the subsequent appearance of the 73K form, suggesting that this subunit form was the product of posttranslational modification of the 77K subunit form in a fashion similar to that seen in PC12 cells. Also, newly synthesized ${ }^{35}$ S-Met-labeled DBH that underwent axonal transport from the LC to the anterior hypothalamus was predominantly the 73K subunit form. A single injection of the catecholaminedepleting drug reserpine (10 $\mathrm{mg} / \mathrm{kg}$, i.p.) produced a 17 -fold increase in the relative synthesis of DBH $2 \mathrm{~d}$ later without affecting the proportion of its 2 subunit forms. Thus, induction of DBH synthesis was regulated separately from the posttranslational modification of its subunit forms.
\end{abstract}

PC1 2 pheochromocytoma cells and sympathetic neurons have been used as models for the expression and regulation of the catecholamine biosynthetic enzymes. The relevance of such studies to neurochemical events occurring in the central nervous system has not been established. A basic knowledge of the synthesis and transport of transmitter-synthesizing enzymes is crit-

\footnotetext{
Received Feb. 28, 1986; revised June 10, 1986; accepted June 12, 1986.

We gratefully thank Dr. Menek Goldstein for the antiserum to rat dopamine $\beta$-hydroxylase, Mr. Edward Agyekum for his excellent technical assistance, and Dr. Susan Wallace for making her densitometer available to us. This work was supported by NIH Grant NS20440 and the Research Service of the Veterans Administration. I.J.K. was a recipient of the American Association of University Women Postdoctoral Fellowship.

Correspondence should be addressed to Dr. Esther L. Sabban, at the above address.

Copyright (C) 1987 Society for Neuroscience $0270-6474 / 87 / 010192-09 \$ 02.00 / 0$
}

ical to our understanding of the regulation of metabolism and function of CNS neurons. In order to study such parameters directly, we conducted in vivo studies on the biosynthesis and transport of dopamine $\beta$-hydroxylase.

Dopamine $\beta$-hydroxylase (DBH) is the enzyme that catalyzes the formation of norepinephrine from dopamine in noradrenergic neurons and adrenal medullary cells (Kaufman and Friedman, 1965). In neurons and in adrenal chromaffin cells, DBH can be found in both membrane-bound and soluble components of the noradrenergic vesicles and chromaffin granules, respectively (Smith and Kirshner, 1967; Lagercrantz, 1976; Winkler, 1976). The characterization of $\mathrm{DBH}$ and its biosynthesis has been well studied in the adrenal medullar and pheochromocytoma cells (cf. Winkler, 1977; Sabban et al., 1983a), while its metabolism in the brain has been less well characterized. DBH has been purified from bovine brain (Bouclier et al., 1978; Matsui et al., 1982) and, while it is immunologically very similar to bovine adrenal $\mathrm{DBH}$, the brain-derived DBH has an apparent molecular weight of 400,000 , as determined by gel filtration, compared to 290,000 for adrenal DBH. Bovine brain DBH has bcen proposed to consist of $90,000 M_{\mathrm{r}}$ subunits with kinetic properties similar to the adrenal enzyme.

In the $\mathrm{PC} 12$ pheochromocytoma cell line, $\mathrm{DBH}$ is a tetrameric enzyme composed of $M_{\mathrm{r}} 77,000(77 \mathrm{~K})$ or $73,000(73 \mathrm{~K})$ subunit forms (Sabban et al. 1983a; McHugh et al., 1985). The $77 \mathrm{~K}$ form is membrane-bound and is the apparent precursor of the $73 \mathrm{~K}$ soluble subunit form (Sabban et al., 1983a). The relative proportions of the 2 subunil forms can be influenced by treatment with nerve growth factor, dexamethasone, dibutyryl cyclic AMP (Sabban et al., 1983b), or the carboxylic ionophore, monensin (Kuhn et al., 1986). The physiological significance of multiple subunit forms of $\mathrm{DBH}$ and whether they might be an idiosyncrasy of tumor cell culture has heretofore been unknown. In this paper, we describe the in vivo biosynthesis and axonal transport of DBH in the noradrenergic neurons of the locus coeruleus (LC) of the rat brain and show that the biosynthesis of DBH and the formation of its subunits are similar in rat brain and PC1 2 cells.

\section{Materials and Methods \\ Materials}

The following materials were purchased from commercial sources: ${ }^{35} \mathrm{~S}$ methionine (1 100-1400 Ci/mmol, $50 \mathrm{mCi} / \mathrm{ml}$ ) from New England $\mathrm{Nu}$ clear; ${ }^{3} \mathrm{H}$-L-amino acid mixture $(273 \mathrm{mCi} / \mathrm{mg})$ from ICN Radiochemicals; ${ }^{14} \mathrm{C}$ molecular weight protein markers from Bethesda Research Laboratories; 6-hydroxydopamine $\mathrm{HBr}$ (6-OHDA) and puromycin from Sigma Chemicals; and Trasylol from Mobay Chemicals. Reserpine (Serpasil) was kindly donated by Ciba-Geigy. 
Sprague-Dawley rats were supplied by Charles River Breeding Labs. The guinea pig antiserum to dopamine $\beta$-hydroxylase from rat pheochromocytoma tumors was kindly provided by Dr. Menek Goldstein, Department of Psychiatry, New York University Medical Center. The preparation and characterization of this antisera have been described in detail by Fong et al. (1980).

\section{Methods}

Labeling of locus coeruleus proteins with ${ }^{35} S$-methionine. The left LC of ether-anesthetized male Sprague-Dawley rats, weighing between 200 and $250 \mathrm{gm}$, were injected over a $15 \mathrm{~min}$ period, using a stereotactic device, by means of a 26-gauge Hamilton microsyringe, with $2 \mu \mathrm{l}$ of ${ }^{35} \mathrm{~S}$-methionine $(1100-1400 \mathrm{Ci} / \mathrm{mmol}, 50 \mathrm{mCi} / \mathrm{ml})$, according to the coordinates of Harik et al. (1981). The rats were killed at various intervals ( $30 \mathrm{~min}$ to $16 \mathrm{hr}$ ) and the regions of the dorsal pons containing the left and right LC were excised (Levin, 1978). The regions weighed about $18 \mathrm{mg}$ per side. Tissue suspensions were prepared by sonication in PBS $(0.15 \mathrm{~m} \mathrm{NaCl}, 10 \mathrm{~mm}$ Na phosphate, $\mathrm{pH} 7.0)$ containing $2 \%$ sodium dodecyl sulfate. The samples were boiled and any insoluble material was removed by centrifugation at $12,800 \times g$. An aliquot of each supernatant was taken to determine incorporation of ${ }^{35} \mathrm{~S}-\mathrm{Met}$ into labeled protein using trichloroacetic acid (TCA) precipitation (Mans and Novelli, 1964). Removal of insoluble material prior to the TCA precipitation did not alter the measurement of ${ }^{35} \mathrm{~S}-$ Met-labeled protein.

Immunoprecipitation of dopamine $\beta$-hydroxylase. Immunoprecipitation of DBH was accomplished by an indirect procedure, using protein A Sepharose (Goldman and Blobel, 1978; Sabban et al., 1981). The cell lysate, in PBS containing 2\% SDS, was boiled for $2 \mathrm{~min}$, diluted with 4 volumes of solution A $(190 \mathrm{~mm} \mathrm{NaCl} ; 50 \mathrm{~mm}$ Tris- $\mathrm{HCl}, \mathrm{pH} 7.4 ; 5$ mм EDTA, 2.5\% Triton X-100; $100 \mathrm{U} / \mathrm{ml}$ Trasylol) and incubated with preimmune guinea pig serum. Insoluble material was removed by centrifugation at $12,800 \times g$ for $30 \mathrm{~min}$. The supernatant was incubated for $16 \mathrm{hr}$ with anti-rat $\mathrm{DBH}$ at $4^{\circ} \mathrm{C}$, then incubated with protein $\mathrm{A}$ Sepharose. The immunoprecipitate was eluted and analyzed by gel electrophoresis.

Gel electrophoresis and fluorography. SDS polyacrylamide slab gel electrophoresis was performed according to a modification (Kreibich and Sabatini, 1974) of the method of Maizel (1971) on 6-12\% gradient gels. Gels were processed for fluorography with sodium salicylate (Chamberlain, 1979) and exposed to prefogged Kodak XAR- 5 film (Laskey and Mills, 1975). Somc of the fluorographs were scanned with a Zeineh soft laser scanning densitometer in order to quantitate relative amounts of the DBH subunit forms.

Subcellular fractionation of $L C$ preparations. ${ }^{35} \mathrm{~S}-\mathrm{Met}-\mathrm{labeled} \mathrm{LC}$ preparations, pooled from 5 rats, were homogenized in ice-cold $0.3 \mathrm{M}$ sucrose containing $100 \mathrm{U} / \mathrm{ml}$ Trasylol and centrifuged at $1000 \times g$ for $10 \mathrm{~min}$. The pellet was resuspended, homogenized as above, and centrifuged at $1000 \times g$ for $10 \mathrm{~min}$. The combined supernatants were centrifuged at $40,000 \times g$ for $10 \mathrm{~min}$. The pellet (crude neurosecretory vesicles) was resuspended by sonication in lysis buffer $(5 \mathrm{~mm}$ Tris- $\mathrm{HCl}$ $100 \mu \mathrm{g} / \mathrm{ml}$ phenylmethylsulfonyl fluoride, and $100 \mathrm{U} / \mathrm{ml}$ Trasylol) and centrifuged at $100,000 \times g$ for $60 \mathrm{~min}$. The supernatant (soluble fraction) was adjusted to $2 \%$ SDS and the pellet (membrane fraction) was suspended by sonication in lysis buffer containing $2 \%$ SDS.

Reserpine treatment. Rats were injected (i.p.) with either $10 \mathrm{mg} / \mathrm{kg}$ reserpine or vehicle. Two days later, ${ }^{35} \mathrm{~S}$-methionine was injected in rat LC using a stereotactic device and, $5 \mathrm{hr}$ later, the rats were killed. ${ }^{35} \mathrm{~S}$ Met-labeled DBH from each individual LC was analyzed by gel electrophoresis and fluorography.

Axonal transport. Injections of ${ }^{35} \mathrm{~S}$-methionine were made into the left LC of rats in which 6-OHDA ( $1 \mu$ l containing $4 \mu \mathrm{g} / \mu \mathrm{l}$ free base) had been injected, $30 \mathrm{~min}$ previously, into the ascending LC pathway in the left rostral forebrain [A 9.0, L 2.0, down $8.0 \mathrm{~mm}$ from the skull (18)] to prevent anterograde transport of DBH proximal to the lesion (Levin, 1981). Injections of 6-OHDA were also made in the posterior hypothalamus into the right medial forebrain bundle, close to the right LC (A 5.0, L 2.0, down $8.4 \mathrm{~mm}$ ) to prevent any transport of labeled material from the right $\mathrm{LC}$ into the hypothalamus. Two days later, the animals were killed and DBH was immunoprecipitated from homogenates of 2 $\mathrm{mm}$ anterior hypothalamus sections removed from the region just proximal to the left forebrain 6-OHDA injection sites (A 7.0-5.0) and from comparable anterior hypothalamic sections from the uninjected side (Levin, 1981).

Inhibition of protein synthesis. The effect of direct injection of puromycin into the LC on subsequent protein synthesis in that area was assessed. An aliquot of ${ }^{3} \mathrm{H}$-labeled L-amino acids (alanine, arginine, aspartic acid, glutamic acid, glycine, histidine, isoleucine, leucine, lysine, phenylalanine, proline, serine, threonine, tyrosine, and valine) containing $20 \mu \mathrm{Ci}$ in a $20 \mu \mathrm{l}$ volume was injected into the lateral ventricle of the cerebrum, followed immediately by injection of $2 \mu$ of the protein synthesis inhibitor, puromycin (10 mM) into either the left or right LC. The contralateral LC was injected with an equal volume of distilled water and the rats ( $n=3$ per time period) were decapitated 30 or 60 min or $16 \mathrm{hr}$ after the puromycin injection. Left and right $\mathrm{LC}$ regions were excised and ${ }^{3} \mathrm{H}$-labeled proteins from each side were precipitated with 10\% TCA (Levin, 1978).

Time course of biosynthesis of dopamine $\beta$-hydroxylase. Ether-anesthesized rats were injected with ${ }^{35} S-M e t$ and the $L C$ were collected after various time intervals ( $30 \mathrm{~min}$ to $16 \mathrm{hr}$ ). In some experiments, protein synthesis was inhibited. A second group of rats was injected in the LC with $2 \mu \mathrm{l}$ of ${ }^{35} \mathrm{~S}$-Met and, $30 \mathrm{~min}$ later, injected in the ipsilateral LC with $2 \mu \mathrm{l}$ of $10 \mathrm{~mm}$ puromycin. The animals were killed after $16 \mathrm{hr}$, and DBH subunit form content was analyzed and quantitated as described above.

\section{Results}

Biosynthesis of ${ }^{35} \mathrm{~S}$-methionine-labeled dopamine

$\beta$-hydroxylase

In order to study the biosynthesis of DBH, ${ }^{35} \mathrm{~S}-\mathrm{Met}$ was injected into the LC on 1 side of the brain of anesthesized rats, using a stereotactic device. Several hours later, the rats were killed and the $\mathrm{LC}$ regions excised from the injected and noninjected sides. Four hours subscquent to labeling with $100 \mu \mathrm{Ci}$ of ${ }^{35} \mathrm{~S}$-methionine, $3.3 \pm 0.54 \times 10^{6} \mathrm{dpm}$ (mean $\pm \mathrm{SE} ; n=16$ ) was incorporated into protein isolated from the injected side. This incorporation was $21.6 \pm 3.0$-fold higher (mean $\pm \mathrm{SE} ; n=6$ ) on the injected side than on the uninjected side. The total profile of ${ }^{35} \mathrm{~S}$-Met-labeled proteins is shown in Figure 1.

DBH was immunoprecipitated and analyzed by gel electrophoresis and fluorography. DBH synthesized during the $4 \mathrm{hr}$ labeling period consisted of near-equal amounts of the $77 \mathrm{~K}$ and $73 \mathrm{~K}$ subunit forms, and was indistinguishable, by electrophoretic migration, from $\mathrm{DBH}$ isolated from the $\mathrm{PC} 12$ pheochromocytoma cell line (Fig. 1). We obtained near-equal amounts of the 2 subunit forms of DBH from the LC of each of the 16 rats examined. Immunoprecipitation was specific, and DBH was not precipitated using preimmune serum. The amount of DBH synthesized was estimated by comparison to the known radioactivity in ${ }^{14} \mathrm{C}$ molecular weight markers. DBH comprised about $0.05-0.1 \%$ of the total ${ }^{35} \mathrm{~S}-\mathrm{Met}$-labeled protein in the LC under these conditions.

To characterize brain $\mathrm{DBH},{ }^{35} \mathrm{~S}$-Met-labeled protein samples obtained from the LC of 5 rats were pooled and fractionated, and a crude fraction containing synaptic vesicles and mitochrondria was isolated according to the method of Coyle and Kuhar (1974). Both subunit forms of DBH werc found in this vesiclc preparation; however, only the $73 \mathrm{~K}$ subunit form of $\mathrm{DBH}$ was released to the soluble fraction upon sonication of the vesicles in hypotonic solution (not shown).

\section{Time course of biosynthesis of subunit forms of dopamine $\beta$-hydroxylase}

In $\mathrm{PC} 12$ cells, DBH is initially synthesized exclusively as a $77 \mathrm{~K}$ subunit form, which is subsequently partially converted to a $73 \mathrm{~K}$ form. After a $90 \mathrm{~min}$ time period, there is a near-equal distribution of the $73 \mathrm{~K}$ and $77 \mathrm{~K}$ forms. We examined the relationship between the subunit forms in the brain to determine whether the $77 \mathrm{~K}$ form might also be the precursor of the $73 \mathrm{~K}$ form in vivo. The time course of biosynthesis of these forms in the LC was examined. The LC was collected after various la- 
TOTAL

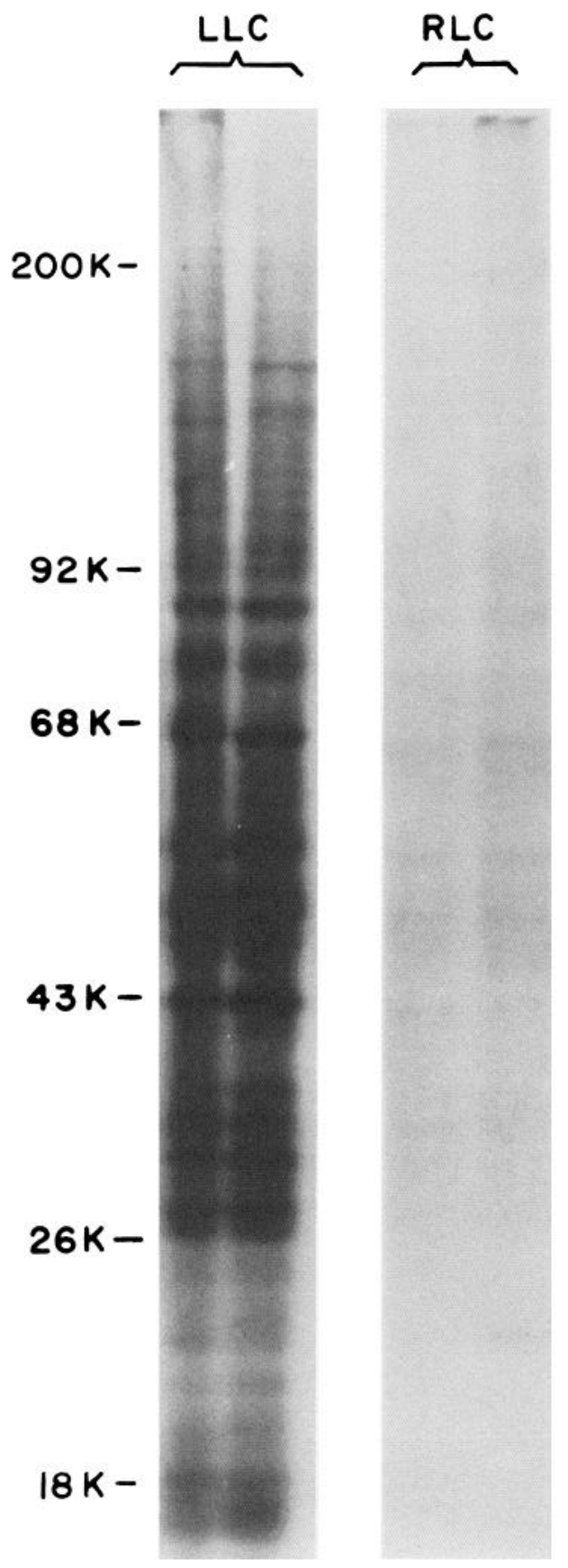

DBH

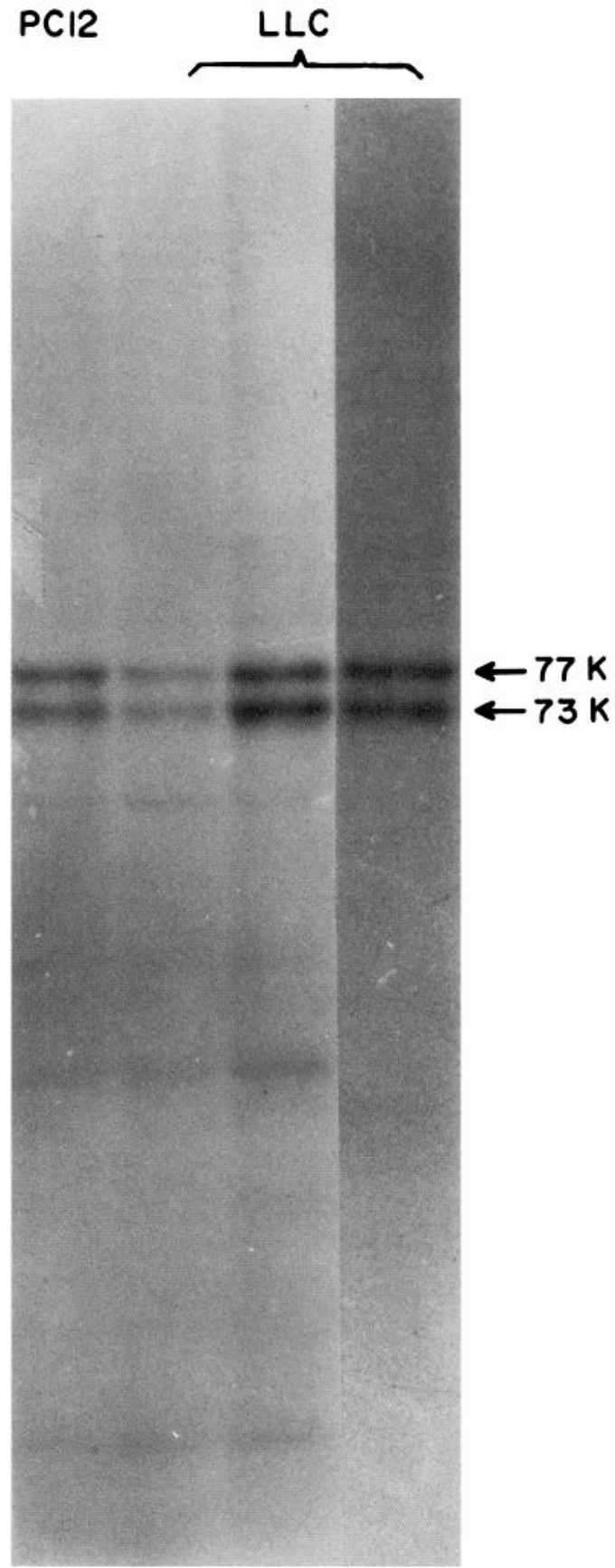

Figure 1. Multiple subunit forms of DBH in rat brain. Ether-anesthetized rats were injected with $2 \mu \mathrm{l}{ }^{35} \mathrm{~S}-\mathrm{Met}$ in the left LC and killed $4 \mathrm{hr}$ later. Homogenized right and left LC samples were pretreated as detailed in Materials and Methods, applied to 6-12\% gradient SDS-polyacrylamide slab gels, and processed for fluorography. The total ${ }^{35} \mathrm{~S}-$ Met-labeled protein profiles from the left ( $L L C$; injected) and right $(R L C$; uninjected) $L C$ are shown in the 4 left-hand lanes. The fluorographs of the immunoprecipitated 77K and 73K subunit forms of DBH (arrows) from PC12 cells and from the left LC of 3 separate rats are shown in the right-hand lanes. Apparent molecular weights, as determined from concomitantly run molecular weight markers, are given on the left side of the figure.

beling times, ranging from $30 \mathrm{~min}$ to $16 \mathrm{hr}$, and ${ }^{35} \mathrm{~S}-$ Met-labeled DBH was analyzed (Figs. 2 and 3). After the shortest labeling time (30 min), $90 \%$ of the DBH was present as the $77 \mathrm{~K}$ subunit form. By 2-5 hr, the 2 subunit forms were present in near-equal proportions, while, by $16 \mathrm{hr}, 2 / 3$ of the DBH was present as the $73 \mathrm{~K}$ subunit form. This showed that the $77 \mathrm{~K}$ subunit form was synthesized first, and suggested that the $77 \mathrm{~K}$ form might, in turn, be processed to the $73 \mathrm{~K}$ subunit form. In order to show that there was a precursor product relationship between the $77 \mathrm{~K}$ and $73 \mathrm{~K}$ subunit forms, we planned to stop protein synthesis $30 \mathrm{~min}$ after ${ }^{35} \mathrm{~S}-\mathrm{Met}$ injection and analyze the subunit forms of DBH several hours later. In preliminary studies, we found that the puromycin treatment inhibited protein synthesis in the LC by $87 \%$ within $30 \mathrm{~min}$, and that inhibition remained sub- 


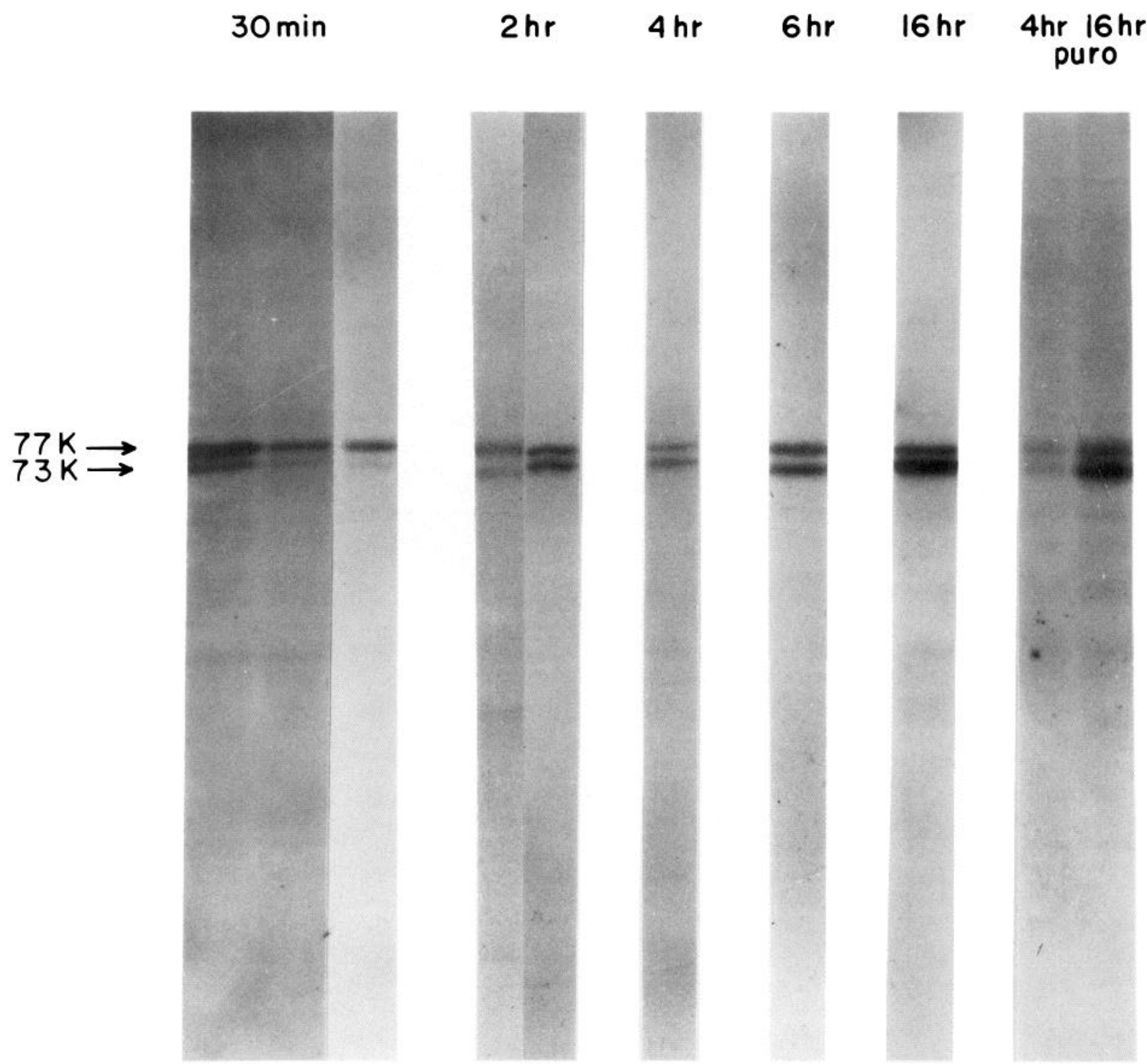

Figure 2. Time course of biosynthesis of subunit forms of DBH. ${ }^{35} \mathrm{~S}-$ methionine $(2 \mu \mathrm{l}$ of $50 \mathrm{mCi} / \mathrm{ml}, 1200 \mathrm{Ci} / \mathrm{mmol})$ was injected over a period of $15 \mathrm{~min}$ into the left LC of ether-anesthetized rats. The rats were killed at the times indicated, the left LC collected, and DBH analyzed by immunoprecipitation, gel electrophoresis, and fluorography. The puromycin-treated animals (puro) were injected in the left LC with $2 \mu \mathrm{l}$ of 10 mM puromycin $30 \mathrm{~min}$ following the injection of ${ }^{35} \mathrm{~S}-\mathrm{Met}$ in the ipsilateral LC, and the LC collected at the times indicated.

stantial (72\%) even $16 \mathrm{hr}$ later (Table 1). Therefore, we proceeded to use puromycin to examine the relationship between the subunit forms. ${ }^{35}$ S-Met was injected into the LC, and 30 min later puromycin was injected to inhibit further protein synthesis. When the rats were killed $16 \mathrm{hr}$ later, DBH was immunoprecipitated and the $73 \mathrm{~K}$ subunit form still represented $78 \%$ of the total DBH present in the LC. These experiments indicated that, in the $\mathrm{LC}$, as in $\mathrm{PC} 12$ cells, the $77 \mathrm{~K}$ subunit form appears to be the precursor that is posttranslationally converted to the $73 \mathrm{~K}$ subunit form.

\section{Axonal transport of dopamine $\beta$-hydroxylase}

To examine the axonal transport of newly synthesized DBH anterograde transport of ${ }^{35} \mathrm{~S}$-Met-labeled DBH was blocked proximal to a 6-OHDA lesion made in the ascending LC pathway. Radiolabeled DBH accumulated in the anterior hypothalamus proximal to the lesion site ipsilateral to the ${ }^{35} \mathrm{~S}$-Metinjected LC over a $2 \mathrm{~d}$ period and no radiolabeled DBH was found on the contralateral side, in which anterograde transport to the anterior hypothalamus had been blocked by a 6-OHDA lesion at LC. The results (Fig. 4) illustrate that predominantly the $73 \mathrm{~K}$ subunit form was transported $(83 \%$ of total transported DBH). It should, however, be noted that, at this time point, the $73 \mathrm{~K}$ subunit form was also the predominant form ( $75 \%$ of total DBH) in the noradrenergic cell bodies in the LC (see Fig. 3, 53 $\mathrm{hr})$.

Effect of reserpine on dopamine $\beta$-hydroxylase synthesis and subunit formation

Reserpine treatment markedly depletes brain catecholamines (Levin, 1980, 1981; Wakade, 1980), induces the synthesis of tyrosine hydroxylase and DBH (Reis et al., 1974, 1975; Ross et al., 1978), and affects their axonal transport (Levin, 1980, 1981). We examined the effect of reserpine on the synthesis of the subunit forms of DBH in the LC, using reserpine treatment conditions identical to those described by Reis et al. (1975) and 
Figure 3. Time course for biosynthesis of the $73 \mathrm{~K}$ subunit form of DBH. The relative proportions of the subunit forms of DBH at various times subsequent to the injection of ${ }^{35} \mathrm{~S}-\mathrm{Met}$ were analyzed by densitometric quantitation of gels similar to those shown in Figure 2. Each point represents a separate LC labeled and immunoprecipitated. The * represents data from puromycintreated animals.

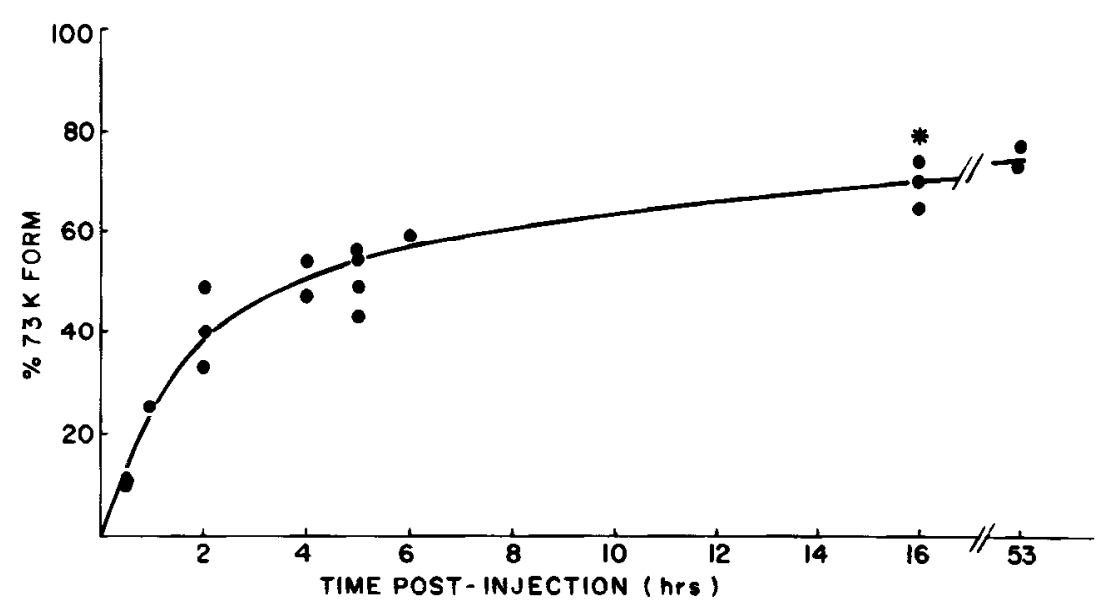

Ross et al. (1978) for maximal induction of brain DBH. Rats were injected with reserpine and, $2 \mathrm{~d}$ later, injected in the LC with ${ }^{35} \mathrm{~S}-\mathrm{Met}$; the LC from individual rats were collected $5 \mathrm{hr}$ subsequently. The electrophoretic profiles of total ${ }^{35} \mathrm{~S}-\mathrm{Met}-\mathrm{la}-$ beled proteins were similar for control and reserpine-treated rats (Fig. 5), suggesting that there were no major changes in the overall pattern of protein synthesis. In 4 sets of control versus reserpine-treated rats, immunoprecipitation of $D B H$ from equal amounts of total ${ }^{35} \mathrm{~S}$-Met-labeled protein samples showed that DBH synthesis was greatly enhanced in reserpine-treated rats (Fig. 6). Quantitation by densitometer scanning of fluorographs indicated that $2 \mathrm{~d}$ after reserpine treatment there was a 17-fold increase in the amount of DBH synthesized in the reserpinetreated rats. Despite the greatly increased amount of DBH synthesized, the relative proportion of the $73 \mathrm{~K}$ subunit form of DBH was not altered in reserpine-treated animals (Table 2; average value $=54.5 \%$ of total ${ }^{35} \mathrm{~S}-\mathrm{DBH}$ in control, $56.8 \%$ of total ${ }^{35} \mathrm{~S}-\mathrm{DBH}$ in reserpine-treated).

\section{Discussion}

The biosynthesis of dopamine $\beta$-hydroxylase has been characterized in the noradrenergic neurons of the rat LC using in vivo labeling with ${ }^{35} \mathrm{~S}$-methionine. This group of about 1500 neurons provides a major noradrenergic innervation to the forebrain as well as the brain stem and spinal cord of the rat (Moore and Bloom, 1979). After 4 to $6 \mathrm{hr}$ of labeling, DBH in LC neurons was always present in near-equal amounts of $77 \mathrm{~K}$ and $73 \mathrm{~K}$ subunit forms. The subunit forms were indistinguishable, by electrophoretic mobility, from the subunit forms of $\mathrm{DBH}$ in PC12 pheochromocytoma cells (Sabban et al., 1983a; McHugh

$\begin{aligned} & \text { Table 1. Effect of puromycin on protein synthesis in the locus } \\
& \text { coeruleus }\end{aligned}$
\begin{tabular}{lll} 
Treatment & \\
\cline { 2 - 3 } Time & Vehicle & Puromycin \\
\hline $30 \mathrm{~min}$ & $5.12 \pm 1.6 \times 10^{5} \mathrm{dpm} / \mathrm{gm}$ & $0.36 \pm 0.04 \times 10^{5} \mathrm{dpm} / \mathrm{gm}$ \\
$60 \mathrm{~min}$ & $7.64 \pm 1.1 \times 10^{5} \mathrm{dpm} / \mathrm{gm}$ & $0.92 \pm 0.010 \times 10^{5} \mathrm{dpm} / \mathrm{gm}$ \\
$16 \mathrm{hr}$ & $3.03 \pm 0.57 \times 10^{5} \mathrm{dpm} / \mathrm{gm}$ & $0.86 \pm 0.19 \times 10^{5} \mathrm{dpm} / \mathrm{gm}$ \\
\hline
\end{tabular}

A mixture of ${ }^{3} \mathrm{H}$ amino acids $(20 \mu \mathrm{Ci})$ was injected intraventricularly and within $5 \mathrm{~min} ; 1 \mathrm{LC}$ was injected with puromycin $(2 \mu \mathrm{l}$ of $10 \mathrm{mM})$ and the other with vehicle $\left(\mathrm{H}_{2} \mathrm{O}\right)$. The rats were killed after the time indicated, the area of the $\mathrm{LC}$ collected, and the radiolabeled TCA-precipitable protein content was determined. a The numbers represent mean $\pm \mathrm{SE} ; n=3$ animals per group. et al., 1985). The results of time-course labeling experiments, as well as studies involving inhibition of protein synthesis using puromycin, showed that DBH in the brain, as in PC12 cells, was initially synthesized as a $77 \mathrm{~K}$ subunit form and subsequently converted to a $73 \mathrm{~K}$ form. This posttranslational conversion appeared to stop at 90 min postsynthesis in PC12 cells, yielding near-equal amounts of both subunit forms in untreated cells, or almost exclusively the $73 \mathrm{~K}$ subunit form in cells treated for several days with nerve growth factor, dexamethasone, or dibutyryl cyclic AMP (Sabban et al., 1983a, b). In the LC, the conversion appeared to continue over a longer time period and to level off only after several hours. By $16 \mathrm{hr}$, about $2 / 3$ of the total $\mathrm{DBH}$ was present as the $73 \mathrm{~K}$ subunit form. We have recently shown that, in PC1 2 cells, the posttranslational processing of the $77 \mathrm{~K}$ to the $73 \mathrm{~K}$ subunit form of $\mathrm{DBH}$ appears to occur prior to its exit from the Golgi apparatus or before acidification of the neurosecretory vesicles (Kuhn et al., 1986). This process may be slower in brain neurons, since a longer time period is required for posttranslational processing of $\mathrm{DBH}$ in the $\mathrm{LC}$.

The proportion of subunit forms of $\mathrm{DBH}$ in PC12 cells was subject to regulation by prolonged treatment (several days) with nerve growth factor, dexamethasone, or dibutyryl cyclic AMP (Sabban et al., 1983b) or short-term treatment with monensin (Kuhn et al., 1986). The monensin treatment also depleted the cells of catecholamines (Perlman et al., 1982; Kuhn et al., 1986). The effect of reserpine on the synthesis of the subunit forms of $\mathrm{DBH}$ in $\mathrm{PC} 12$ cells and in the $\mathrm{LC}$ was examined. Reserpine treatment has a very pronounced effect on catecholamines, and

Table 2. Effect of reserpine on biosynthesis of dopamine $\beta$-hydroxylase

\begin{tabular}{|c|c|c|c|c|c|c|}
\hline & & \multicolumn{3}{|l|}{ Area $^{a}$} & \multicolumn{2}{|c|}{ Percentage } \\
\hline & & $77 \mathrm{~K}$ & $73 \mathrm{~K}$ & Total & $77 \mathrm{~K}$ & $73 \mathrm{~K}$ \\
\hline \multirow[t]{2}{*}{ Control } & $\mathrm{C}_{1}$ & 12,826 & 11,123 & 23,949 & 46.4 & 53.5 \\
\hline & $\mathrm{C}_{2}$ & 12,961 & 10,432 & 23,393 & 44.5 & 55.5 \\
\hline \multirow[t]{4}{*}{ Reserpine } & $\mathbf{R}_{1}$ & 274,044 & 208,198 & 482,242 & 43.2 & 56.8 \\
\hline & $\mathbf{R}_{2}$ & 203,237 & 137,323 & 340,560 & 40.3 & 59.7 \\
\hline & $\mathbf{R}_{3}$ & 250,378 & 200,978 & 451,356 & 44.5 & 55.5 \\
\hline & $\mathbf{R}_{4}$ & 22,080 & 17,750 & 39,830 & 44.6 & 55.4 \\
\hline
\end{tabular}

The immunoprecipitates of DBH from the LC of individual rats shown in Figure 6 were scanned and an average taken from 3 scans. Controls $C_{3}$ and $C_{4}$ were below the level of detection.

${ }^{a}$ Area is expressed in relative densitometer units. 


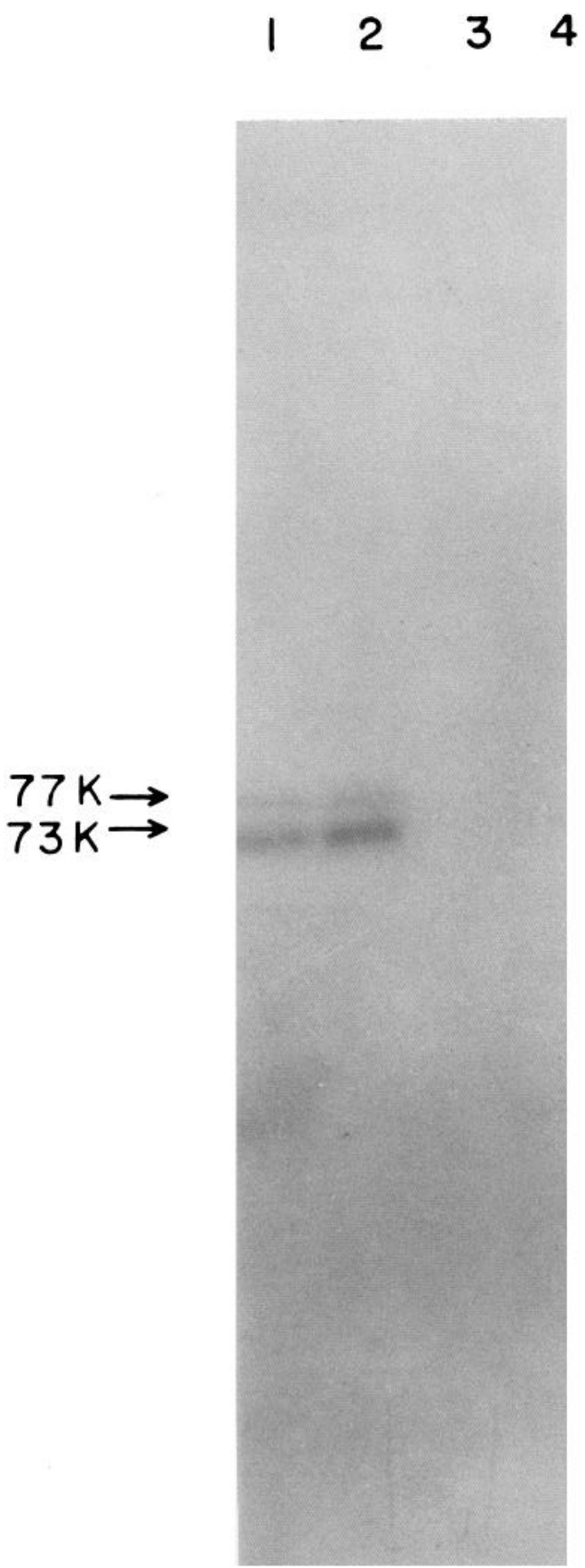

Figure 4. Axonal transport of DBH in LC neurons. ${ }^{35}$ S-Met-labeled DBH synthesized in the left LC and transported to the ipsilateral hypothalamus accumulated over a $2 \mathrm{~d}$ period proximal to a $6-\mathrm{OHDA}$ lesion placed in the left ascending LC pathway in the rostral forebrain. ${ }^{35}$ S-Met-labeled DBH from the left anterior hypothalamus proximal to the forebrain lesion (lanes 1 and 2) or from the comparable right (lanes 3 and 4 ) anterior hypothalamic sections in which transport of DBH had been blocked by a 6-OHDA lesion placed in the proximal LC pathway, close to the LC, was immunoprecipitated and analyzed by gel electrophoresis and fluorography.

a single injection into rats leads to a dramatic long-term effect of depletion of brain catecholamines (Carlsson et al., 1957; Levin, 1980; 1981; Wakade, 1980). Several days after a single injection of reserpine, it was noted that the specific activities of both $\mathrm{DBH}$ and tyrosine hydroxylase in the noradrenergic cell

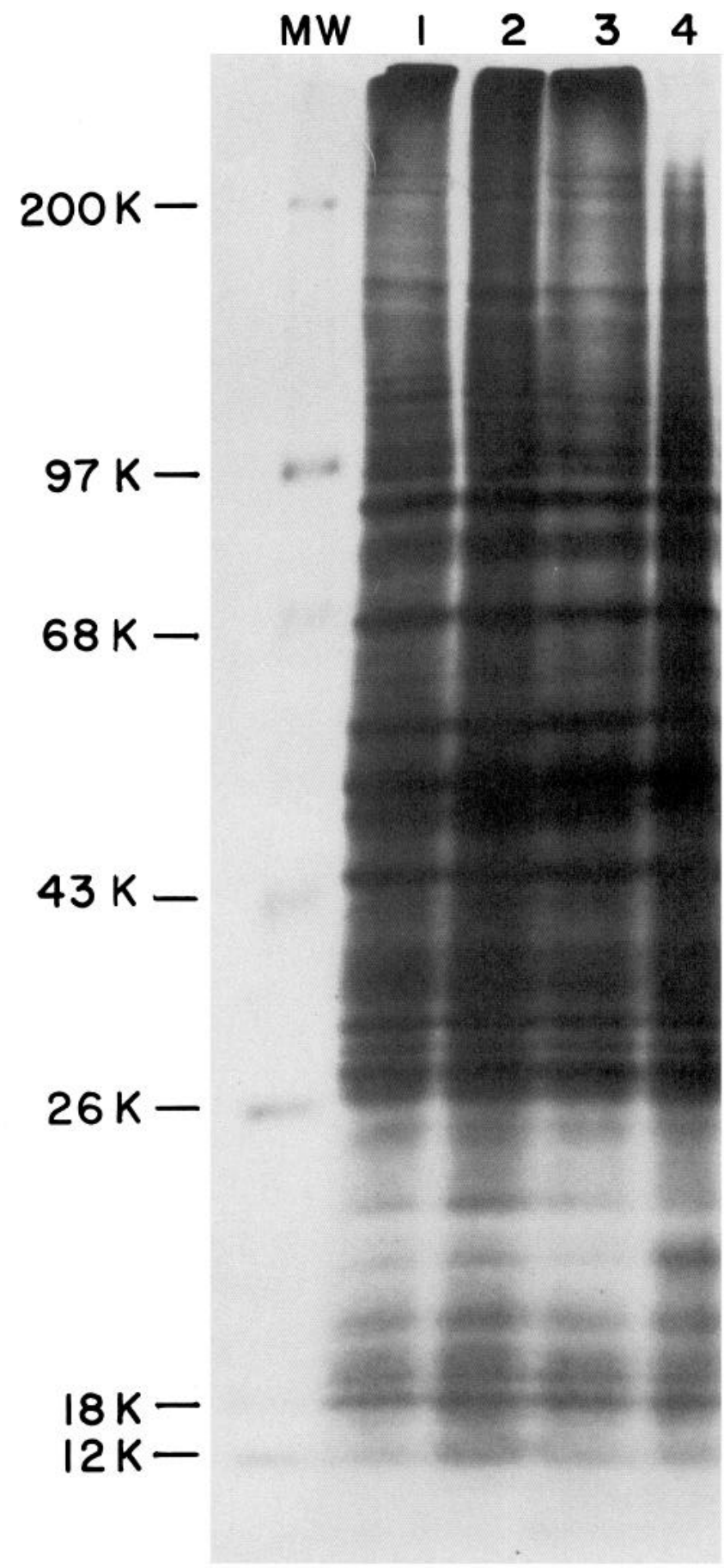

Figure 5. Effect of reserpine on protein synthesis in the LC. Two days following a single injection of reserpine $(10 \mathrm{mg} / \mathrm{kg}$, i.p. $),{ }^{35} \mathrm{~S}$-methionine was injected into the $\mathrm{LC}$ and labeling continued for a $5 \mathrm{hr}$ period. The electrophoretic profile of ${ }^{35} \mathrm{~S}$-Met-labeled proteins $(150,000 \mathrm{dpm})$ from the area of the LC is shown. Reserpine-treated (lanes 1 and 2); controls (lanes 3 and 4).

bodies of the LC had increased nearly 2-fold (Reis et al., 1974; Brooke and Fibiger, 1975). The increase in tyrosine hydroxylase activity in reserpine-treated animals was a result of enhanced mRNA levels in the LC and was maximal $2 \mathrm{~d}$ after a single injection of reserpine (Mallet et al., 1983; Biguet et al., 1986). Immunotitration studies showed that the increase in DBH activity in reserpine-treated animals was due to the accumulation 


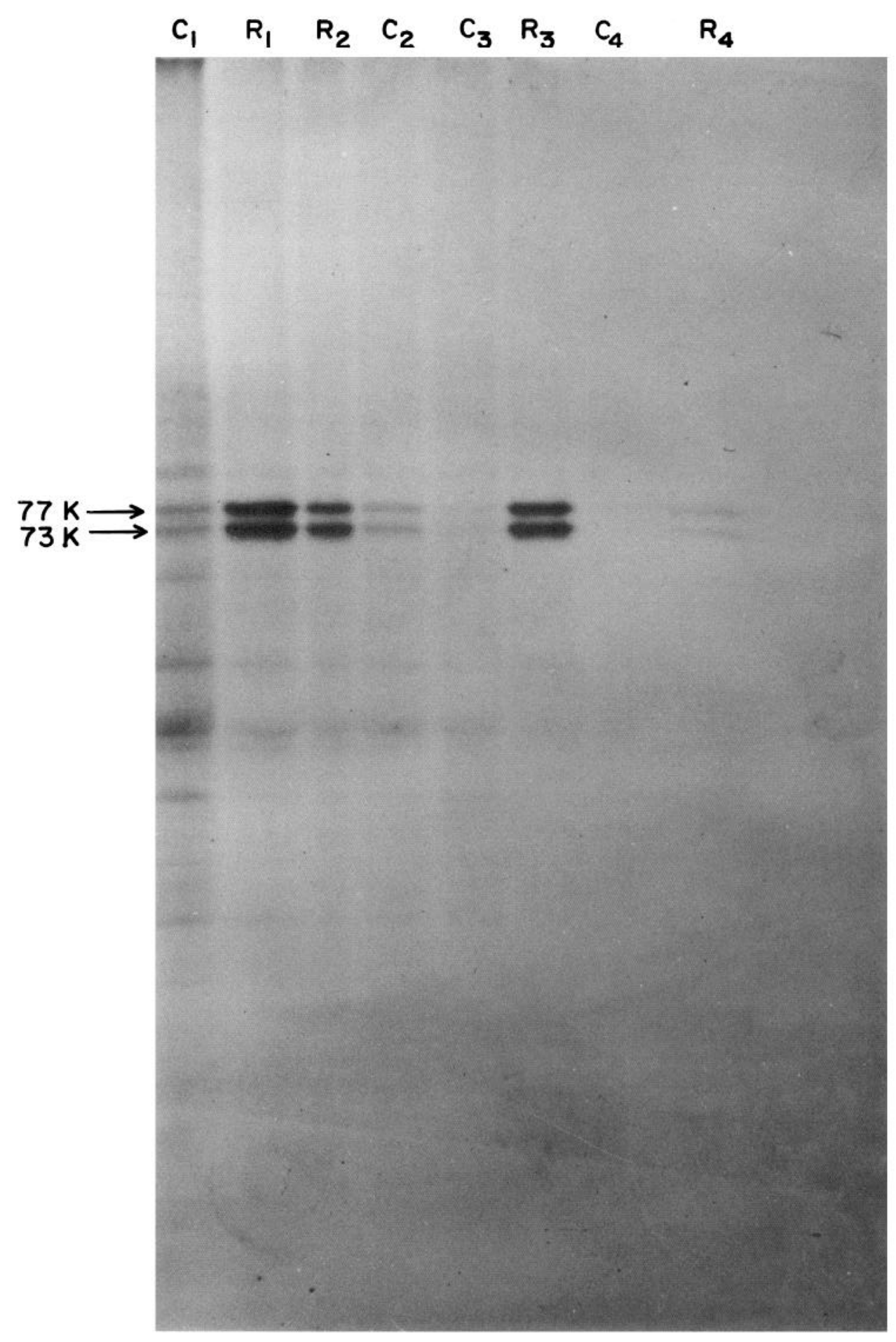

Figure 6. Effect of reserpine on biosynthesis of DBH. The electrophoretic profiles of ${ }^{35} \mathrm{~S}-$ Met-labeled DBH from controls $(C)$ or reserpine-treated $(R)$ rats are shown. Each lane represents DBH from a separate rat. Lanes $C_{l}, C_{2}, R_{l}$, and $R_{2}$ are immunoprecipitates from $1.5 \times 10^{6} \mathrm{dpm}$, lanes $C_{3}$ and $R_{3}$ from $7.5 \times 10^{5} \mathrm{dpm}$, and lanes $C_{4}$ and $R_{4}$ from $1.5 \times 10^{5} \mathrm{dpm}$ of total TCA-precipitable protein.

of specific enzyme protein (Reis et al., 1975). Such an accumulation could result from enhanced synthesis or decreased turnover. The present study also established that there was an apparent enhancement of synthesis of DBH in the LC of reserpine-treated rats.

Our experiment showed that, $2 \mathrm{~d}$ after a single injection of reserpine, there was a 17 -fold increase in the amount of DBH synthesized. These results are higher than those observed by Ross et al. (1978), who used ${ }^{3} \mathrm{H}$ amino acids and found a 1.9fold increase $3 \mathrm{~d}$ after reserpine treatment. In their experiments, the immunoprecipitates were only $10-15 \% \mathrm{DBH}$, and therefore they had to slice and count the gel. They were unable to detect DBH directly by electrophoresis. We chose to examine the synthesis after $2 \mathrm{~d}$ since that corresponded to the beginning of the increase in DBH activity (Reis et al., 1975).

While the amount of DBH synthesized was markedly increased after reserpine treatment, there was no effect on the proportion of subunit forms of $\mathrm{DBH}$, and these forms remained in near-equal amounts after a $5 \mathrm{hr}$ labeling period. We also found that treatment of $\mathrm{PC} 12$ cells with reserpine, under con- 
ditions that depleted the cells of catecholamines, did not alter the proportion of the subunit forms of DBH. These experiments suggest that regulation of the amount of DBH synthesized is independent of regulation of the relative proportion of the subunit forms of DBH resulting from posttranslational modification. The regulation of the proportion of the subunit forms may reflect the relative amount of the putative processing enzyme, or the amount of time DBH spends in the Golgi apparatus prior to entry into an acidic compartment.

The DBH in the brain was present in a vesicular fraction, and the soluble form of DBH in the LC appeared to consist exclusively of the $73 \mathrm{~K}$ subunit form. DBH, isolated from a variety of tissues, is known to be present in a membrane-bound and soluble form within the neurosecretory vesicle. The biochemical nature of the differences between these forms and the relative proportion of these subunit forms in a variety of tissues are subjects open to considerable controversy. Several investigators have failed to detect differences between membrane-bound and soluble forms of $\mathrm{DBH}$, and reports indicate that DBH consists of 4 identical glycosylated subunits with molecular weights of about 75,000 (Park et al., 1976; Fong et al., 1980; Rush and Geffen, 1980). On the other hand, Bjerrum et al. (1979) differentiated an amphiphilic, membrane-bound form from a hydrophilic, soluble form of bovine DBH using crossed immunoelectrophoresis. Slater et al. (1981) noted subtle differences between peptide maps of soluble and membrane-bound DBH, while Sokoloff et al. (1985) did not find intraspecies differences in amino acid composition or peptide maps of soluble and membrane-bound DBH from bovine adrenal medulla or human pheochromocytoma tumor. Saxena and Fleming (1983) characterized the membrane-bound form of DBH from bovine adrenal and found it to be different from the soluble form. They suggested that the membrane-bound form contained 2 nonidentical subunits, as well as bound phospholipid.

In the rat $\mathrm{PC} 12$ pheochromocytoma cell line, we showed that DBH was present as a $77 \mathrm{~K}$ membrane-bound subunit form and a $73 \mathrm{~K}$ soluble subunit form in near-equal amounts (Sabban et al., 1983a). The DBH that is secreted concomitantly with catecholamines consists of the 73K subunit form (Kuhn et al., 1985; McHugh et al., 1985), but it may differ from the soluble form in carbohydrate or sulfate composition. McHugh et al. (1985) confirmed the presence of the $77 \mathrm{~K}$ and $73 \mathrm{~K}$ subunit forms of DBH in PC12 cells, and concurred in finding the soluble form to be comprised of $73 \mathrm{~K}$ subunits. However, they contended that the membrane form consists of both $77 \mathrm{~K}$ and $73 \mathrm{~K}$ subunits. Their results may be due to incomplete osmotic lysis of their vesicles, whereas we used sonication in hypotonic media to isolate DBH from PC12 cells (Sabban et al., 1983a). Inadequate lysis of vesicles may have allowed soluble DBH trapped in unlysed vesicles to sediment with the membrane fraction obtained by McHugh et al. (1985). Alternately, our fractionation procedure (Sabban et al., 1983a) may have been too harsh, leading to the dissociation of $73 \mathrm{~K}$ subunits from the membrane.

Examination of the subcellular distribution of DBH in neurons in the peripheral and central nervous systems has been more complicated, and DBH may be present in more than 1 type of vesicle (Belmar et al., 1974; Klein et al., 1979). There is also disagreement regarding the relative proportions of soluble and membrane-bound forms of DBH in neurons, since Gasparis et al. (1983) showed that noradrenergic vesicles from neurons arc more difficult to lyse in hypotonic media than are chromaffin granules, and DBH can be released from noradrenergic vesicles more efficiently using a French press. We attempted to use a French press to homogenize the LC tissue, but it appeared to be too harsh and seemed to release membrane-bound DBH into the soluble fraction, possibly by fragmentation of the membrane. We were, however, able to show that both subunit forms of DBH in the LC were present in near-equal proportions $(5 \mathrm{hr}$ labeling time) in a crude vesicle fraction, and that only the $73 \mathrm{~K}$ subunit form was released by sonication in hypotonic media. These results are consistent with previous findings that indicated that the soluble DBH consisted of the $73 \mathrm{~K}$ subunit form, but we are unable to ascertain whether the membrane form of DBH in the brain consisted exclusively of the $77 \mathrm{~K}$ form or whether the $73 \mathrm{~K}$ subunit form was also normally part of the membranebound DBH.

The axonal transport of newly synthesized DBH could be monitored by its accumulation proximal to a specific catecholamine neurotoxin lesion in the anterior hypothalamus. The transport of proteins from rat locus coeruleus to the hypothalamus has been shown to occur in 5 successive waves (Levin, 1978). Norepinephrine and DBH appear to travel in the second wave at 24-48 mm/d (Levin and Stolk, 1977; Levin, 1979). In our study, predominantly the $73 \mathrm{~K}$ subunit form of DBH appeared to be transported, and thus the soluble form may predominate within vesicles moving along the axons of $L C$ neurons (Levin, 1979). The proportion of subunit forms transported to the anterior hypothalamus was similar to that in the cell bodies of the locus coeruleus at the same time. Thus, DBH may undergo most of its posttranslational processing from the $77 \mathrm{~K}$ to the $73 \mathrm{~K}$ form prior to its transport, as would be indicated by experimental results with PC12 cells, which showed that the posttranslational processing of DBH occurred prior to the exit of DBH from the Golgi apparatus or acidification of the vesicles (Kuhn et al., 1986).

In conclusion, in vivo labeling of rat brain DBH has shown that the enzyme is present as 2 subunit forms and that there is a precursor-product relationship between these forms, as seen in PC12 cells. Subcellular distribution of the forms in brain appears to be similar to that found in PC12 cells, and reserpine treatment causes an increase in DBH biosynthesis but not alteration of posttranslational processing in both in vivo and in vitro systems. These findings indicate that the PC12 pheochromocytoma cell line appears to be a valid system for the study of the principles involved in the biosynthesis of dopamine $\beta$-hydroxylase.

\section{References}

Belmar, J., W. P. DePotter, and A. F. DeSchaepdryver (1974) Subcellular distribution of noradrenaline and dopamine $\beta$-hydroxylase in the hypothalamus of the rat. Evidence for the presence of two populations of noradrenergic storage particles. J. Neurochem. 23: 607-609.

Biguet, N. F., M. Buda, A. Lamouroux, D. Samolyk, and J. Mallet (1986) Time couse of the changes of TH mRNA in rat brain and adrenal medulla after a single injection of reserpine. EMBO J. 5: 287291.

Bjerrum, O. J., K. B. Helle, and E. Bock (1979) Immunochemically identical hydrophilic and amphiphilic forms of the bovine adrenomedullary dopamine $\beta$-hydroxylase. Biochem. J. 181: 231-237.

Bouclier, M., M. Pescheloche, P. Mandel, and D. Aunis (1978) Properties of partially purified bovine brain dopamine $\beta$-hydroxylase. Biochimic 60: 127-136.

Brooke, S. M., and H. C. Fibiger (1975) Differential rates of increase of pontine tyrosine hydroxylase and dopamine $\beta$-hydroxylase activities after reserpine. Brain Res. 85: 532-534.

Carlsson, A., E. Rosengren, A. Bertler, and J. Nelsson (1957) The 
effect of reserpine on the metabolism of catecholamines. In Psychotropic Drugs, S. Garattini and V. Ghetti, eds., pp. 363-372, Elsevier, Amsterdam.

Chamberlain, J. P. (1979) Fluorographic detection of radioactivity in polyacrylamide gels with the water-soluble fluor, sodium salicylate. Anal. Biochem. 98: 132-135.

Coyle, J. T., and M. J. Kuhar (1974) Subcellular localization of dopamine $\beta$-hydroxylase and endogenous norepinephrine in the rat hypothalamus. Brain Res. 65: 475-487.

Fong, J. C., L. Shenkman, and M. Goldstein (1980) Purification and characterization of rat pheochromocytoma dopamine $\beta$-hydroxylase. J. Neurochem. 34: 346-350.

Gasparis, M. S., W. H. Yank, and R. L. Klein (1983) Hydrophilic form of dopamine $\beta$-hydroxylase from purified noradrenergic neurons. Activities and comparisons. Neurochem. Res. 8: 1417-1439.

Goldman, B. M., and Blobel, G. (1978) Biogenesis of peroxisomes: Intracellular site of synthesis of catalase and uricase. Proc. Natl. Acad. Sci. USA 75: 5066-5070.

Harik, S. I., R. B. Duckrow, J. C. LaManna, M. Rosenthal, V. K. Sharma, and S. P. Banerjee (1981) Cerebral compensation for chronic noradrenergic denervation induced by locus ceruleus lesion: Recovery of receptor binding isoproterenol-induced adenylate cyclase activity and oxidative metabolism. J. Neurosci. I: 641-649.

Kaufman, S., and S. Friedman (1965) Dopamine $\beta$-hydroxylase. Pharmacol. Rev. 17: 71-100.

Klein, R. L., A. K. Thureson-Klein, S. H. C. Yen, J. McBaggett, M. S. Gasparis, and D. F. Kirksey (1979) Dopamine $\beta$-hydroxylase distribution in density gradients: Physiological and artifactual implications. J. Neurobiol. 10: 291-307.

Kreibich, G., and Sabatini, D. D. (1974) Selective release of content from microsomal vesicles without membrane disassembly. II. Electrophoretic characterization of microsomal subfractions. J. Cell Biol. 61: 789-807.

Kuhn, L., E. Sabban, and M. Goldstein (1985) Dopamine beta-hydroxylase glycoprotein in PC12 cells: Secretion and oligosaccharide characterization. Fed. Proc. 44: 3840.

Kuhn, L. J., M. Hadman, and E. L. Sabban (1986) Effect of monensin on synthesis, post-translational processing, and secretion of dopamine $\beta$-hydroxylase from PC12 pheochromocytoma cells. J. Biol. Chem. 261: 3816-3825.

Lagercrantz, H. (1976) On the composition and function of large dense cored vesicles in sympathetic nerves. Neuroscience 1: 81-92.

Laskey, R. A., and A. D. Mills (1975) Quantitative film detection of ${ }^{3} \mathrm{H}$ and ${ }^{14} \mathrm{C}$ in polyacrylamide gels by fluorography. Eur. J. Biochem. 56: $335-341$.

Levin, B. E. (1978) Axonal transport of $\left[{ }^{3} \mathrm{H}\right]$ proteins in a noradrenergic system of the rat brain. Brain Res. 150: 55-68.

Levin, B. E. (1979) The use of neurotoxins to characterize the rates and subcellular distributions of axonally transported dopamine $\beta$-hydroxylase, tyrosine hydroxylase and norepinephrine in the rat brain. Brain Res. I68: 331-350.

Levin, B. E. (1980) Effects of reserpine on fast, intermediate and slow axonal transport of proteins in rat locus coeruleus neurons. Brain Res. 189: 495-504.

Levin, B. E. (1981) Reserpine effect on axonal transport of dopamine $\beta$-hydroxylase and tyrosine hydroxylase in rat brain. Exp. Neurol. 72: 99-112.

Levin, B. E., and J. M. Stolk (1977) Axonal transport of norepinephrine in the locus coeruleus hypothalamic system in the rat. Brain Res. 120: 303-315

Maizel, J. V., Jr. (1971) Polyacrylamide gel electrophoresis of viral proteins. In Methods in Virology, Vol. 5, K. Maramorosch and K. Kaprowski, eds. pp. 179-245, Academic, New York.

Mallet, J., N. F. Biguet, M. Buda, A. Lamouroux, and D. Samolyk (1983) Detection and regulation of the tyrosine hydroxylase mRNA levels in rat adrenal medulla and brain tissues. Cold Spring Harbor Symp. Quant. Biol. 48: 305-308.
Mans, R. J., and Novelli, G. C. (1964) Measurement of the incorporation of radioactive amino acids in proteins by a filter paper disk assay. Arch. Biochem. Biophys. 94: 48-53.

Matsui, H., C. Yamamoto, and T. Nagatsu (1982) Purification and properties of bovine brain dopamine $\beta$-hydroxylase. J. Neurochem. 39: 1066-1071.

McHugh, E. M., R. McGee, Jr., and P. J. Fleming (1985) Sulfation and constitutive secretion of dopamine $\beta$-hydroxylase from rat pheochromocytoma (PC12) cells. J. Biol. Chem. 260: 4409-4417.

Moore, R. Y., and F. E. Bloom (1979) Central catecholamine neuron systems: Anatomy and physiology of the norepinephrine and epinephrine systems. Annu. Rev. Neurosci. 2: 113-168.

Park, D. H., T. Kashimoto, R. P. Ebstein, and M. Goldstein (1976) Purification and immunochemical characterization of dopamine $\beta$-hydroxylase from human pheochromocytoma. Mol. Pharmacol. 12: 73-81.

Perlman, R. L., B. E. Sheard, A. S. Tischler, and P. W. I. L. Kwan (1982) Monensin depletes $\mathrm{PC1} 2$ pheochromocytoma cells of catecholamines and of catecholamine-typc granules. Neurosci. Lett. 29: 177-182.

Reis, D. J., T. H. Joh, and R. A. Ross (1975) Effect of reserpine on activities and amounts of tyrosine hydroxylase and dopamine $\beta$-hydroxylase in catecholamine neuronal systems in rat brain. J. Pharmacol. Exp. Ther. 193: 775-784.

Reis, D. J., T. H. Joh, R. A. Ross, and V. M. Pickel (1974) Reserpine selectively increases tyrosine hydroxylase and dopamine $\beta$-hydroxylase enzyme protein in central noradrenergic neurons. Brain Res. 81 : 380-386.

Ross, R. A., T. H. Joh, and D. J. Reis (1978) Increase in the relative rate of synthesis of dopamine $\beta$-hydroxylase in the nucleus locus coeruleus elicited by reserpine. J. Neurochem. $81: 1491-1500$.

Rush, R. A., and L. B. Geffen (1980) Dopamine $\beta$-hydroxylase in health and disease. Crit. Rev. Clin. Lab. Sci. 12: 241-277.

Sabban, E. L., L. A. Grcenc, and M. Goldstein (1983a) Mcchanism of biosynthesis of soluble and membrane-bound forms of dopamine $\beta$-hydroxylase in PC12 pheochromocytoma cells. J. Biol. Chem. 258: 7812-7818.

Sabban, E. L., M. Goldstein, and L. A. Greene (1983b) Regulation of the multiple forms of dopamine $\beta$-hydroxylase by nerve growth factor, dexamethasone and dibutyryl cyclic AMP in the PC12 pheochromocytoma cell line. J. Biol. Chem. 258: 7819-7823.

Sabban, E., V. Marchesi, M. Adesnik, and D. D. Sabatini (1981) Erythrocyte membrane protein band 3: Its biosynthesis and incorporation into membranes. J. Cell Biol. 91: 637-646.

Saxena, A., and P. J. Fleming (1983) Isolation and reconstitution of the membrane-bound form of dopamine $\beta$-hydroxylase. J. Biol. Chem. 258: 4147-4152.

Slater, E. P., S. Zarcmba, and R. A. H. Hogue-Angeletti (1981) Purification of membrane-bound dopamine $\beta$-monooxygenase from chromaffin granules: Relation to soluble dopamine $\beta$-monooxygenase. Arch. Biochem. Biophys. 211: 288-296.

Smith, W. J., and N. Kirshner (1967) A specific soluble protein from the catecholamine storage vesicles of bovine adrenal medulla. I. Purification and chemical characterization. Mol. Pharmacol. 3: 52-62.

Sokoloff, R. L., R. P. Frigon, and D. T. O'Connor (1985) Dopamine $\beta$-hydroxylase: Structural comparisons of membrane-bound versus soluble forms from adrenal medulla and pheochromocytoma. J. Neurochem. 44: 41 1-420.

Wakade, A. R. (1980) A comparison of rates of depletion and recovery of noradrenaline stores of peripheral and central noradrenergic neurons after reserpine administration: Importance of neuronal activity. Br. J. Pharmacol. 68: 93-98.

Winkler, H. (1976) The composition of adrenal chromaffin granules: An assessment of controversial results. Neuroscience 1: 65-80.

Winkler, H. (1977) The biogenesis of adrenal chromaffin granules. Neuroscience 2: 657-683. 